\title{
Analysis of high-mountain vegetation of the Kurai Ridge
}

\author{
Ekaterina Popova* and Evgeniy Sinkovskiy \\ Central Siberian Botanical Garden SB RAS, 630090 Novosibirsk, Russia
}

\begin{abstract}
The paper presents a taxonomic, areographic and belt-andzonal analysis of the high-mountain flora of the Kurai Ridge. The flora of the region in question contains 312 species of plants, referred to 143 genera belonging to 48 families. Analysis of the taxonomic structure of the high-mountain flora of the Kurai Ridge has shown the following most abundant plant families: Asteraceae, Ranunculaceae, and Poaceae. For the variety of the genera, the following genera are predominant: Carex, Pedicularis, Salix, and Oxytropis. The areographic analysis has demonstrated that the said species are of the North Asian (21\%), South Siberian $(19.4 \%)$ and Holarctic $(17.4 \%)$ origins. Dominant in the beltand-zonal range are the following species: high-mountain $(23.2 \%)$, lightconiferous forest (17.7\%) and Arctic Alpine (17.4\%) species. In general, the composition and structure of the high-mountain flora of the Kurai Ridge are determined by its geographic position at the boundary of Central and South-Eastern Altai and by decrease in the amount of precipitation in the south-eastern direction.
\end{abstract}

\section{Introduction}

The caenotic and floristic variety of the high-mountain belt of the Kurai Ridge is related to its geographic position, variability of the landscape forms, the composition of the rocks forming it and inhomogeneity of the climatic conditions. All these factors lead to formation of great caeno-floristic variety in the small territory [1]. Over the recent years, the relevance of studying the high-mountain flora of Altai has considerably grown due to essential changes in the character of its economic development.

P.N. Krylov's works contain the first data on the floristic variety of the highlands of Altai; he was also the first to identify the belt-zonal groups in the high-mountain vegetation of Altai.

The most complete and detailed data on the high-mountain vegetation are contained in the works by A.V. Kuminova [2] and V.P. Sedelnikov [1]. In the works by M.P. Danilov $[3,4]$, the inventory is taken of the ridge flora, with taxonomic and geographic analysis made based on the obtained data.

The objective of the study: to make the taxonomic, areographic, and belt-and-zonal analysis of the high-mountain flora of the Kurai Ridge.

\footnotetext{
* Corresponding author: katina-popova@yandex.ru
} 


\section{The area of the study}

The Kurai Ridge is a mountain range which serves as a watershed of the two biggest rivers of the Katun and Chulyshman basins (the Chuya and Bashkaus Rivers). It is of south-east north-west trending within the Ulagan and Kosh-Agach districts of the Republic of Altai. It is $140 \mathrm{~km}$ long and $40 \mathrm{~km}$ wide. The ridge stretches in the north-western direction from the Chikhachev Ridge to the Aigulak Ridge. The Sarulukol Depression is north-west of it, the valley of the Bashkaus River is in the north, and the Kurai and Chuya Depressions are in the south. The highest peak of the ridge, $3,446 \mathrm{~m}$, is situated in the upper reaches of the Ortolyk River $[5,6]$. The climate of the territory under study is sharply continental, the average air temperature in January is $-32.1^{\circ} \mathrm{C}$ and $+13^{\circ} \mathrm{C}$ in July The total annual precipitation is $110 \mathrm{~mm}$. The vegetation period lasts from 50 to 70 days.

In accordance with the floristic zoning carried out by S.I. Molokanov [7], six floristic districts - Kurai, Aktash, Chuya, Kokorya, Kavuri, and Saratan districts - have been identified on the Kurai Ridge. Kosh-Agach (745 species) is the most floristically abundant district, which is related to the presence of all the vegetation belts in its territory, from the steppe belt to the nival belt.

The high-mountain vegetation of the Kurai Ridge is subdivided into two belts: subalpine and alpine.

The subalpine belt stretches from 1,800-2,500 m asl. In the vegetation cover, the formation Betula rotundifolia prevails in the complex with subalpine meadows. Highmountain and meadow steppes commonly occur on the southern slopes of the subalpine belt. Tallgrass subalpine meadows occur in the north-western part of the Kurai Ridge, and their grass tier consists of Aconitum altaicum, Delphinium elatum, Saussurea latifolia, Stemmacantha carthamoides, etc. Lowgrass subalpine meadows occupy riverine habitats, while in the grassy tier Astragalus frigidus, Geranium richardsonii, Rhodiola rosea, and Saussurea frolowii prevail.

Alpine or alpinotype meadows (Sedelnikov, 1985) occur on the bottoms of trough valleys and in the snow patch and riverine habitats (Poa alpina, Ranunculus altaicus, Viola altaica). The vegetation of the mountain tundra complex is represented by dwarf birch thickets consisting of Betula rotundifolia, Salix glauca, S. vestita, of lichens Cetraria islandica, Cladonia arbuscula, and Flavocetraria cucullate; while in the grassy tier Carex stenocarpa and Festuca sphagnicola dominate. In the high-mountain range of 2,000-2,500 m, Kobresia communities of Kobresia myosuroides and $K$. simpliciuscula occupy the dominant position. The mountain avens tundras (Dryas oxyodonta) are formed in the upper part of the mountain tundra belt, rising to the altitude of $2700 \mathrm{~m}$. The nival belt stretches from 2,600 to $3,000 \mathrm{~m}$ on the rocks, where plant communities of cryophyte cushion plants are formed, consisting of Potentilla biflora, Rhodiola quadrifida, S. oppositifolia, and Sibbaldia tetrandra.

\section{Results and discussion}

The flora of the high-mountain belt of the Kurai Ridge consists of 312 species of higher vascular plants, which refer to 143 genera from 48 families. Angiosperms are prevalent, with 301 species present, constituting $96.5 \%$ of the total number of species. Cryptogam plants are represented by 4 species, while gymnosperms are represented by 7 species (Table 1).

Analysis of the taxonomic structure of the high-mountain flora of the Kurai Ridge has shown the following families to be abundant in species: Asteraceae $(9 \%)$, Ranunculaceae (7.8\%), Poaceae (7\%), Caryophyllaceae (6.1\%), Rosaceae (6.1\%), Cyperaceae (5.8\%), 
Scrophulariaceae (5.8 \%), Fabaceae (5.4\%), Apiaceae (4.8\%), and Gentianaceae (4.2\%) (Table 2). These families include 193 species, which is $61.9 \%$ of the total flora. Certain families are also present, which are scarce in terms of the species composition but play a significant role in forming the high-mountain vegetation, with Alliaceae, Boraginaceae, Brassicaceae, Ericaceae, Lamiaceae, Polygonaceae, Primulaceae, Salicaceae, and Saxifragaceae among them. These families include 65 species, which constitutes $20.8 \%$ of the total flora.

Table 1. Composition of systematic groups of the high-mountain flora of the Kurai Range

\begin{tabular}{|c|c|c|c|c|c|c|}
\hline $\begin{array}{c}\text { Systematic } \\
\text { group }\end{array}$ & $\begin{array}{c}\text { Number of } \\
\text { families }\end{array}$ & $\begin{array}{c}\text { Total number } \\
\text { of families, } \%\end{array}$ & $\begin{array}{c}\text { Number of } \\
\text { genera }\end{array}$ & $\begin{array}{c}\text { Total number } \\
\text { of genera, \% }\end{array}$ & $\begin{array}{c}\text { Number of } \\
\text { species }\end{array}$ & $\begin{array}{c}\text { Total number } \\
\text { of species, \% }\end{array}$ \\
\hline $\begin{array}{c}\text { Cryptogam } \\
\text { plants }\end{array}$ & 1 & 2 & 1 & 0,7 & 4 & 1,3 \\
\hline Gymnosperm & 3 & 6,3 & 6 & 4,2 & 7 & 2,2 \\
\hline Angiospermae & 44 & 91,7 & 136 & 95,1 & 301 & 96,5 \\
\hline Total & 48 & 100 & 143 & 100 & 312 & 100 \\
\hline
\end{tabular}

Table 2. Number of species of the main families in the flora of the high mountain belt of the Kurai Range

\begin{tabular}{|c|l|c|c|}
\hline Rank & Family & $\begin{array}{c}\text { Number of } \\
\text { species }\end{array}$ & $\begin{array}{c}\text { Total } \\
\text { number of } \\
\text { species, } \%\end{array}$ \\
\hline 1 & Asteraceae & 28 & 9 \\
\hline 2 & Ranunculaceae & 24 & 7,8 \\
\hline 3 & Poaceae & 22 & 7 \\
\hline $4-5$ & Caryophyllaceae & 19 & 6,1 \\
\hline $4-5$ & Rosaceae & 19 & 6,1 \\
\hline $6-7$ & Cyperaceae & 18 & 5,8 \\
\hline $6-7$ & Scrophulariaceae & 18 & 5,8 \\
\hline 8 & Fabaceae & 17 & 5,4 \\
\hline 9 & Apiaceae & 15 & 4,8 \\
\hline 10 & Gentianaceae & 13 & 4,2 \\
\hline
\end{tabular}

For the variety of genera, the following genera are dominant: Carex (9.8\%), Pedicularis (7,7\%), Salix (7 \%), Oxytropis (5.6\%), Potentilla (5.6\%), Gentiana (4.9\%), Aconitum (4.9\%), Saxifraga (4.9\%), Allium (4.9\%), and Saussurea (4.2\%). These genera contain 85 species, which is $27.2 \%$ of the total composition of the flora (Table 3 ).

Table 3. The genus spectrum of the high-mountain flora of the Kurai Range

\begin{tabular}{|c|l|c|c|}
\hline Rank & Genus & $\begin{array}{c}\text { Number } \\
\text { of } \\
\text { species }\end{array}$ & $\begin{array}{c}\text { Total } \\
\text { number of } \\
\text { species, } \%\end{array}$ \\
\hline 1 & Carex & 14 & 9,8 \\
\hline 2 & Pedicularis & 11 & 7,7 \\
\hline 3 & Salix & 10 & 7 \\
\hline $4-5$ & Oxytropis & 8 & 5,6 \\
\hline $4-5$ & Potentilla & 8 & 5,6 \\
\hline $6-9$ & Gentiana & 7 & 4,9 \\
\hline $6-9$ & Aconitum & 7 & 4,9 \\
\hline $6-9$ & Allium & 7 & 4,9 \\
\hline $6-9$ & Saxifraga & 7 & 4,9 \\
\hline 10 & Saussurea & 6 & 4,2 \\
\hline
\end{tabular}


The areographic analysis was made based on the comprehensive study of the data provided in the works by L.I. Malyshev and G.A. Peshkova [8]. Analysis is one of the main sources for revealing the details of the floristic genesis. Izt showed predominance of the North Asian species (21\%), which is related to development of the most recent centers of species formation within the boundaries of the long trans-Asian mountain belt. The endemic species of the Kurai Ridge are the most specific component of the flora, reflecting the autochthonous trend in the flora development. 24 endemic species were identified among the high-mountain flora, which accounted for $7.7 \%$ of the total flora, the greater part of which grows in rocky and arid habitats (Fig. 1).

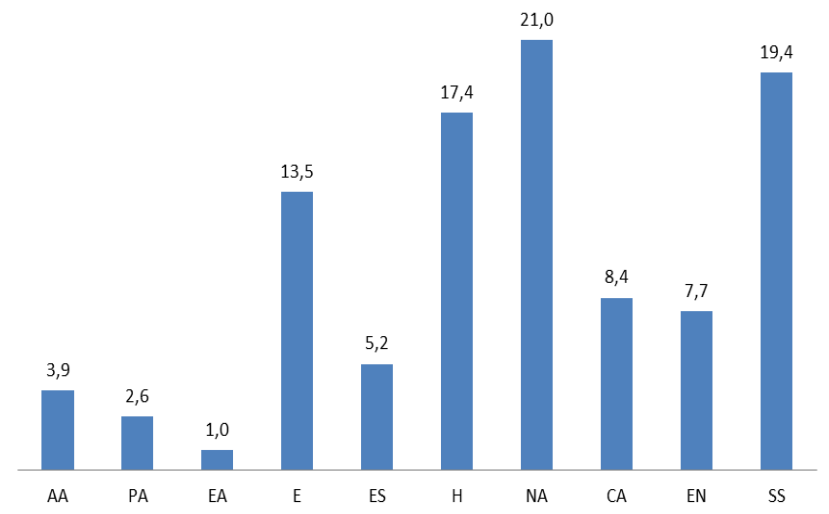

Fig.1. Areological structure of the high-mountain flora of the Kurai Range. AA - American-Asian, PA - Pan-Asian, EA - East Asian, E - Eurasian, ES - Euro-Siberian, H - Holarctic, NA - North Asian, CA - Central Asian, EN - Endemic, SS - South Siberian.

The belt-zonal analysis of the floristic structure allows us to evaluate the regional floras in terms of compliance of its composition with the current orographic and climatic conditions and allows us to identify the features testifying to the stages of the evolution of the flora. The results of the analysis showed that most species are related to the highmountain belt-zonal complex (23.2\%), which is typical of the Kurai Ridge (Fig. 2).

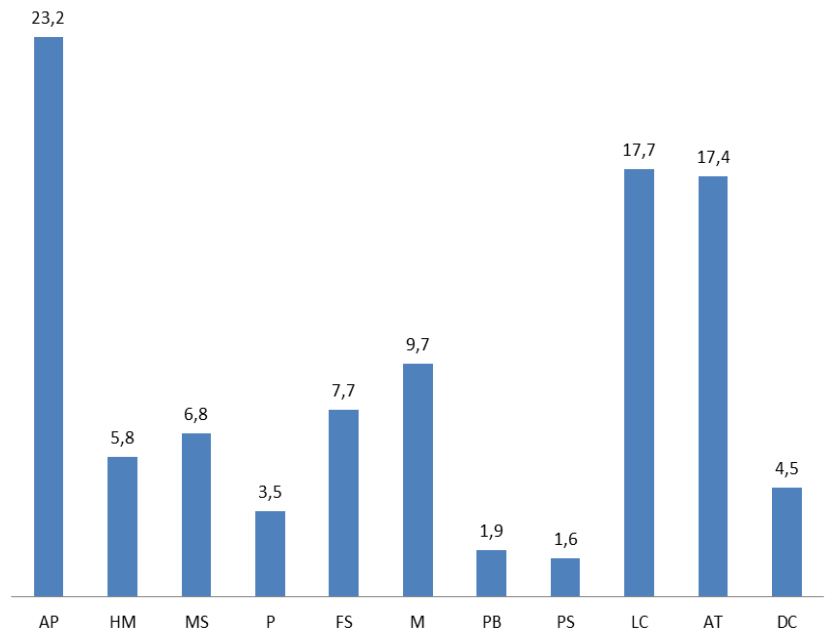

Fig.2. The belt-zonal composition of the high-mountain flora of the Kurai Range. AP - alpine or alpine proper, HM - hyparkomontana, MS - mountain steppe, P - pratal, FS - forest-steppe, M - 
montane, PB - preboreal, PS - proper steppe, LC - light coniferous forest, AT - alpine tundra or arctoalpine, DC - dark coniferous forest.

\section{Conclusion}

The study of the floristic composition of the high-mountain vegetation of the Kurai Ridge has revealed 312 species of the higher vascular plants, belonging to 143 genera from 48 families.

The taxonomic analysis conducted has demonstrated 10 dominant families of the highmountain flora: Asteraceae (9 \%), Ranunculaceae (7.8\%), Poaceae (7 \%), Caryophyllaceae (6.1\%), Rosaceae (6.1\%), Cyperaceae (5.8\%), Scrophulariaceae (5.8 $\%)$, Fabaceae (5.4\%), Apiaceae (4.8\%), and Gentianaceae (4.2\%). These families accounted for more than $60 \%$ of the total composition of the flora. In addition, several families should be mentioned which are scarce in terms of the species composition but which play a significant role in forming high-mountain vegetation, among which Alliaceae, Boraginaceae, Brassicaceae, Ericaceae, Lamiaceae, Polygonaceae, Primulaceae, Salicaceae, and Saxifragaceae may be indicated. 65 species belonged to those families, which constituted $20.8 \%$ of the total composition of the flora. For the variety of the flora, the following genera were found to be predominant: Carex $(9.8 \%)$, Pedicularis $(7.7 \%)$, Salix (7 \%), Oxytropis (5.6\%), Potentilla (5.6\%), Gentiana (4.9\%), Aconitum (4.9\%), Saxifraga (4.9\%), Allium (4.9\%), and Saussurea (4.2\%). 85 species belonged to the above genera, which constituted $27.2 \%$ of the total flora.

The areographic analysis has shown predominance of the North-Asian species (21\%), which is related to development of the most recent centers of species formation within the boundaries of the long trans-Asian mountain belt (Sochava,1948; Malyshev, 2002). There are 24 endemic species among the high-mountain flora, which accounts for $7.7 \%$ of the total flora. The greater part of them is concentrated in rocky and arid habitats. The belt-andzonal analysis of the flora has shown that most species are related to the high-mountain belt-and-zonal complex (23.2\%), which is typical of the Kurai Ridge.

\section{References}

1. V. P. Sedelnikov, High-mountain vegetation of the Altai-Sayan Mountains (Novosibirsk, 1988)

2. A. V. Kuminova, The vegetation of the Altay (Novosibirsk, 1960)

3. M. P. Danilov, Botanical J., 73 (1988)

4. M. P. Danilov, Proceedings of the USSR Academy of Sciences, Biological Series, 3 (1989)

5. L. K. Zyatkova, Structural geomorphology of the Sltai-Sayan mountain region (Novosibirsk, 1977)

6. I. S. Novikov, Morphotectonics of the Altai (Novosibirsk, 2004)

7. S. I. Molokanov, Bulletin of Altai State University, 1 (2013)

8. L. I. Malyshev, G. A. Peshkova, Peculiarities and genesis of the flora of Siberia (Baikal region and Transbaikalia) (Novosibirsk, 1984) 